\title{
The Use of Guidebook on Socio-Personal Guidance for Autism Children
}

\author{
Endang Pudjiasuti Sartinah, Lisdiana Putri Dewi Anggraini \\ Departement of Special Education \\ Universitas Negeri Surabaya \\ Surabaya, Indonesia \\ endangsartinah@unesa.ac.id
}

\begin{abstract}
Enhancing a social interaction of children with autism at the school is challenging. Therefore, a guidebook for teachers regarding building social interaction among children with autism is essential. The purpose of this guidebook is to help teachers to improve children with autism social interaction. Thus, this research aims to understand the teachers' reception using guidebook on socio-personal guidance to improve social interaction among children with autism in an inclusive school. This research applied a quantitative approach. Data were collected through a questionnaire and analyzed with simple statistic descriptive. The results showed that teacher guidebook in personal social guidance with role-playing technique to increase social interaction of children with autism in inclusive school is well accepted by teachers as teachers' responses towards the use of this guidebook are positive.
\end{abstract}

Keywords—socio-personal; guidance; children with autism; inclusive school

\section{INTRODUCTION}

Children with autism have special characteristics in the aspects of social interaction, communication and behaviour, this agrees with the opinion of Matson [1] who states that "For instances, disturbances in response to sensory stimuli, incident on sameness, impaired verbal and nonverbal communication, and self-stimulation, are all now considered to be the common characteristics of autism". Moreover, children with ASD perform social deficits which involve difficulties initiating social initiation and responding to initiations performed by others. Developing social interactions of children with autism in the school environment is challenging [2], so there needs to be guidance from the teacher to build social interaction of children in the environment. Indonesia's Government Regulation No. 72 of 1991 Chapter XII Article 28 Paragraph I state that guidance is an assistance provided to students to meet their personal needs and overcome their problems.

In overcoming the problem of social interaction of children with autism, guidance techniques are needed [3][4] - one of the guidance techniques is the role-playing technique. The technique of role-playing has two kinds of definition. First, role-playing is an act of character. It means that some players and figures play a specific role, the role is following the character that has been written in the scenario, and the purpose of playing this role is to provide entertainment to others. Second, the role-playing technique is a sociological activity, where the patterns in behaviour shown by a person are determined by social norms that live in the community.
Role-playing techniques are very useful in facilitating students in learning social behaviour and values [5]; (1) reallife can be presented and analogous to role-playing scenarios, (2) role-playing can describe students' authentic feelings, both those that are only thought and expressed, (3) emotions and ideas that appear in role-play can let to an awareness, which in turn will give direction to change, and (4) invisible psychological processes related to attitudes, values, and belief systems can let to an awareness through spontaneous play and analysis. The role-playing technique that is applied in this case is role-playing, where children with autism will be asked to play a role whose characteristics are different from the child's self so that the child can understand the feelings experienced by others.

By understanding the meaning and purpose of the roleplaying technique, individuals are expected to be able to overcome interpersonal problems and be able to interact socially well, especially children with autism. These factors greatly determine the success of students in realizing themselves as individuals who are able to socialize in the environment, especially for children with autism. The statement was also expressed by [6] who states that children with autism have a disorder of passive development with abnormal function characteristics in three areas, namely social interaction, communication, and limited and repetitive behaviour, so that they are unable to express feelings and desires so that behaviours and relationships with others become disrupted.

In reality, there are children with autism who are still lacking in socializing, the lack of self-awareness in parents in dealing with these problems results in children with autism difficult to put themselves in a new environment or outside environment [7]. Most parents feel children with autism do not need more handling in terms of social interaction, but this increasingly makes children with autism limit themselves and their lack of self-confidence when they are around, especially when around their friends, children with autism tend to show more selfishness, even children with autism will withdraw when joining other people.

Previous research by [8] on the effectiveness of using role-playing techniques in social, personal guidance to improve social interaction in grade eight of Public Junior High School 8 in Kediri, Indonesia shows that by giving social, personal guidance, children are able to socialize well with role-playing techniques that are done with their classmates. So, it can be concluded that the implementation of personal social guidance using role-playing techniques is able to develop the independence of socializing children. The 
difference in research now with the previous is in terms of subject, place, material, and aspects of research. Moreover, a study by Corbet et al. [9] reported that by implementing peer-mediated theatrical treatment, social skills of students with ASD could be improved. Another study by Alzyoudi, Sartawi and Almuhiri [10] indicated that children with ASD could improve their social skills by modelling.

Based on observations at Gunung Anyar Elementary School 273 Surabaya, Indonesia there are several children with autism who have problems in social interaction, this can be seen from the behaviour of children who like to be alone and never socialize with friends when learning in class and during recess. The results of interviews with several classroom teachers at the school found that children with autism tend to withdraw from their friends. It was due to a lack of self-awareness of parents about the importance of socializing for children with autism. Besides, based on the results of interviews with Special Education Teacher, the school found that children were invited to play with their friends, but because children's selfishness was still high, their friends chose to withdraw and avoid children with autism in the school.

In connection with these problems, it is necessary to have assistance or guidance for schools so that schools are able to provide guidance services that are able to train children with autism in terms of socializing in addition to developing academic children with autism. One strategy that can be suggested to help develop social interactions in children with autism is the provision of guidance services tailored to the needs and characteristics of children with autism. In order to help teachers in providing guidance services for children with autism, a personal social guidance guide is printed into a guidebook. The personal social guidance guidebook is a guide to developing social interactions in children with autism which are the result of the development of preexisting guidelines but are still general and limited to all students, both regular and special needs with different types of disabilities.

Teacher's guidebook in personal social guidance consists of (1) foreword, the contents of the introductory words show the gratitude of the author, (2) preliminary, it contains background on personal social guidance guidebooks and theories regarding the relevance of the contents of the socio-personal guidance guidebook, which is about children with autism, social interaction, socio-personal guidance, and role-playing techniques, (3) steps to implement a personal social guidance guide. It contains the stages that must be done by the teacher before the commencement of personal social guidance and when given personal social guidance.

However, the results of the development of this guide are only focused on children with autism. Therefore, this research sought to know the teachers' reception on using a guidebook to develop social interactions in children with autism in an inclusive elementary school.

\section{METHOD}

This research applied a quantitative approach to the type of data collection method using a closed questionnaire. A total of 2 teachers from Gunung Anyar Elementary School 237 Surabaya answered questions based on a Likert scale with a category of Score 4 for very good categories, a score of 3 for a good category, a score of 2 for a fairly good category and a score of 1 for less [11]. Furthermore, the data were analyzed through the use of simple descriptive statistics.

\section{RESULTS AND DISCUSSION}

A questionnaire was given to special education teachers in Gunung Anyar Elementary School 273 Surabaya totalling as many as two teachers by analyzing the teacher's response to teacher guidebook in socio-personal guidance with roleplaying techniques to improve the social interaction of children with autism. Teacher questionnaire responses to this guidebook aim to obtain input from the teacher on the teacher's guidebook. The teacher's questionnaire to the development of this guidebook was completed by the teacher after using the guidebook. Scoring scores for each indicator in this questionnaire used a Likert scale consisting of 4 assessment criteria. Score 4 for a very good category, score 3 for good category, score 2 for a quite good category and score 1 for less good [11]. As for the results of this questionnaire is shown in figure one.

$$
\begin{aligned}
M_{x} & =\frac{\sum x}{N} \\
& =\frac{32.5}{10} \\
& =3.2
\end{aligned}
$$

\section{Fig. 1. Results of the Teachers' Response}

Based on figure 1, it can be seen that teachers' reception on the guidebook is positive (3.2 out of 4 ). Its positive reception is particularly because this book could help them delivering socio-personal guidance for their students with autism. The success of the teacher in providing socio-personal guidance by using role-playing techniques to improve the social interaction of children with autism due to the availability of teacher guidebooks, with a guide for socio-personal guidance teachers can facilitate teachers to provide personal social guidance whose steps have been facilitated by researchers and using media who are favored by children with autism to facilitate the teacher in providing personal social guidance with role-playing techniques. Indeed, a study by Otero et al. [12] and a study by Kasari and Smith [13] asserted that an intervention for improving social skills should be specially created to meet the needs of children with autism. This is in line with the study by Akmanoglu, Yanardag and Batu [14] which reported that graduated guidance is effective in teaching social skills among children with autism. Indeed, a study Daneshvar, Charlop and Malmberg [15] showed that structured guidance is essential to teach social skills for children with autism.

The teacher creates an atmosphere that can build the social interaction of children with autism, through social interaction, there will be interrelationships between individuals to create a mutually beneficial relationship. In general, Hamre [16] reported that cognitively stimulating and responsive interaction between teachers and students are important to support students' development. Indeed, a study by Laugeson et 
al. [17] reported that teacher-facilitated social skills training could improve the social skills of children with autism. This agrees with Bimo [18] social interaction is the relationship between individuals one with another individual, individual one can influence another individual or vice versa, so there is a mutual relationship.

Teachers can provide a special service to help children with autism in solving problems of social interaction, one of which is by giving personal social guidance. It is supported by studies by [19] and Plavncik, Kaid and MacFarland [20] which reported that school-based guidance could help develop students with autism social skills. Socio-personal guidance is a service that is given to solve problems that exist in the individual related to social problems. This is consistent with Yusuf and Nurihsan's opinion [21] which states that Social-Personal guidance is guidance to assist individuals in solving personal social problems, such as relationships with friends/teachers, understanding the nature and abilities self, adjustment to the educational/residential environment, and conflict resolution.

\section{CONCLUSION}

This personal social guidebook can be used by teachers to improve the social interaction of children with autism in inclusive schools. Teachers' reception on this guidebook was positive. Firstly, it is because of this guidebook prepared in an interactive manner. Thus, it increased the interest of children to carry out activities with the roleplaying technique. Secondly, by using this guidebook, teachers were able to create a supportive learning atmosphere for enhancing students with autism social interaction skills.

\section{REFERENCES}

[1] J. Matson, Autism in children and adults. California: Brooks/Cole, 1994.

[2] K. A. Pituch et al., "Parent reported treatment priorities for children with autism spectrum disorders," Res. Autism Spectr. Disord., vol. 5, no. 1, pp. 135-143, 2011.

[3] L. Centelles, C. Assaiante, K. Etchegoyhen, M. Bouvard, and C. Schmitz, "From action to interaction: exploring the contribution of body motion cues to social understanding in typical development and in autism spectrum disorders," J. Autism Dev. Disord., vol. 43, no. 5, pp. 1140-1150, 2013.

[4] K. A. Gibson, "Appreciating the world of autism through the lens of video interaction guidance: an exploration of a parent's perceptions, experiences and emerging narratives on autism," Disabil. Soc., vol. 29 , no. 4, pp. 568-582, 2014.
[5] U. Herlina, "Teknik Role Playing Dalam Konseling Kelompok," Sos. Horiz. J. Pendidik. Sos., vol. 2, no. 1, pp. 94-107, 2016.

[6] Y. Azwandi, "Mengenal dan Membantu Penyandang Autisme," Jakarta Dep. Pendidik. Nas., 2005.

[7] S. P. H. Camargo, M. Rispoli, J. Ganz, E. R. Hong, H. Davis, and R. Mason, "A review of the quality of behaviorally-based intervention research to improve social interaction skills of children with ASD in inclusive settings," J. Autism Dev. Disord., vol. 44, no. 9, pp. 20962116, 2014.

[8] E. D. Utari, "EFEKTIVITAS PENGGUNAAN TEKNIK BERMAIN PERAN (ROLE PLAYING) DALAM BIMBINGAN PRIBADI SOSIAL UNTUK MENINGKATKAN INTERAKSI SOSIAL PADA SISWA KELAS VIII SMP NEGERI 8 KEDIRI TAHUN PELAJARAN 2016/2017," Universitas Nusantara PGRI Kediri, 2017.

[9] B. A. Corbett, L. R. Qualls, B. Valencia, S.-M. Fecteau, and D. M. Swain, "Peer-mediated theatrical engagement for improving reciprocal social interaction in autism spectrum disorder," Front. Pediatr., vol. 2, p. 110, 2014.

[10] M. Alzyoudi, A. Sartawi, and O. Almuhiri, "The impact of video modelling on improving social skills in children with autism," $\mathrm{Br} . J$. Spec. Educ., vol. 42, no. 1, pp. 53-68, 2015.

[11] Sugiyono, Metode Penelitian Kuantitatif, Kualitatif, dan Kombinasi (Mixed Methods). Bandung: Alfabeta, 2014.

[12] T. L. Otero, R. B. Schatz, A. C. Merrill, and S. Bellini, "Social skills training for youth with autism spectrum disorders: a follow-up," Child Adolesc. Psychiatr. Clin., vol. 24, no. 1, pp. 99-115, 2015.

[13] C. Kasari and T. Smith, "Interventions in schools for children with autism spectrum disorder: Methods and recommendations," Autism, vol. 17, no. 3, pp. 254-267, 2013.

[14] N. Akmanoglu, M. Yanardag, and E. S. Batu, "Comparing video modeling and graduated guidance together and video modeling alone for teaching role playing skills to children with autism," Educ. Train. autism Dev. Disabil., pp. 17-31, 2014.

[15] S. D. Daneshvar, M. H. Charlop, and D. Berry Malmberg, "A treatment comparison study of a photo activity schedule and Social Stories for teaching social skills to children with Autism Spectrum Disorder: brief report," Dev. Neurorehabil., vol. 22, no. 3, pp. 209214, 2019.

[16] B. K. Hamre, "Teachers' daily interactions with children: An essential ingredient in effective early childhood programs," Child Dev. Perspect., vol. 8, no. 4, pp. 223-230, 2014.

[17] E. A. Laugeson, R. Ellingsen, J. Sanderson, L. Tucci, and S. Bates, "The ABC's of teaching social skills to adolescents with autism spectrum disorder in the classroom: The UCLA PEERS ${ }^{\circledR}$ program," J. Autism Dev. Disord., vol. 44, no. 9, pp. 2244-2256, 2014.

[18] W. Bimo, "Pengantar psikologi umum," Yogyakarta Andi Offset, 2004.

[19] J. H. Barnett, "Three evidence-based strategies that support social skills and play among young children with autism spectrum disorders," Early Child. Educ. J., vol. 46, no. 6, pp. 665-672, 2018.

[20] J. B. Plavnick, T. Kaid, and M. C. MacFarland, "Effects of a schoolbased social skills training program for adolescents with autism spectrum disorder and intellectual disability," J. Autism Dev. Disord., vol. 45, no. 9, pp. 2674-2690, 2015.

[21] S. Yusuf and J. Nurihsan, "Landasan bimbingan dan konseling," Bandung: Remaja Rosdakarya, vol. 30, 2005. 